\title{
Courts, Cabinet and Coalition Parties: The Politics of Euthanasia in a Parliamentary Setting
}

\author{
BERNARD STEUNENBERG*
}

\begin{abstract}
An analysis is made of the interaction between the legislature and the judiciary in the Dutch parliamentary setting, focusing in particular on the issue of euthanasia. Using the methodology of positive political theory, two alternative hypotheses are derived about the extent to which the courts may affect public policies. Two main conclusions can be drawn from the analysis of the decision-making process on euthanasia. First, the statutory interpretation the courts gave on euthanasia in the 1980s supports the hypothesis of the court as a policy advocate, not a policy conserver. Secondly, the fact that the courts were able to introduce and maintain a more liberal interpretation of euthanasia during the last decade can be explained as a consequence of the heterogenous preferences on this issue held by the political parties that formed the successive governing coalitions.
\end{abstract}

At the end of 1993, after a political debate that had lasted more than fifteen years, the Dutch parliament accepted a statutory regulation that conferred on the minister of justice and the minister of welfare, health and cultural affairs the power to set standards about the way a physician must report a case of euthanasia to the public prosecutor. Until then, a physician had had to establish a person's cause of death according to law. If someone died of illness or old age, the physician delivered an official statement that the person died from 'natural causes', after which the body could be buried or cremated. In all other cases, a physician was obliged to inform the authorities, who then examined the body and decided whether or not an official inquiry had to be made. The new regulation requires a physician who practises euthanasia to submit a report. ${ }^{1}$ Shortly after the bill was enacted, both ministers subsequently drafted a ministerial ruling stipulating the many issues that had to be addressed in the physician's statement. These issues include the patient's illness and its development; the kind, content and moment of the request by the patient to end

* Faculty of Public Administration and Public Policy, University of Twente. I thank Jan van Deth and the referees and Editors of this Journal for helpful comments and suggestions. The paper benefited from discussions at seminars at the Department of Political Science, University of North Carolina at Chapel Hill, the Center for Study of Public Choice, George Mason University, Virginia, and the Annual Meeting of the American Political Science Association at Chicago, 1994. Furthermore, I would like to thank Jacqueline Douven for her research assistance. Financial support was provided by the Netherlands Institute of Government (NIG).

${ }_{1}$ This also holds for assisted suicide and the ending of a life without the consent of the person involved. Since assisted suicide is regarded as being similar to euthanasia in regard to its legal consequences, it will not be distinguished from euthanasia in this article. 
his or her life; and the way in which euthanasia had been applied, including the extent to which another physician was consulted. The statute was preceded by several other proposals, including a bill proposed by the opposition. In contrast to most of these proposals, the current regulation does not address the extent to which euthanasia is admissible, nor the conditions under which euthanasia is legally permitted. Euthanasia - that is, the ending of a life with the consent of the person involved - remains a criminal offence and will not be removed from the Criminal Law. As the minister of justice repeatedly stressed during the parliamentary discussion, the Act does not legalize euthanasia, but only aims to improve the prosecution's ability to assess those physicians who have practised euthanasia. $^{2}$

This administrative solution to the euthanasia debate stands in sharp contrast to existing jurisprudence. Starting in the early 1980s, the Dutch courts began to develop new interpretations of the prohibition of euthanasia, as laid down in the Code of the Criminal Law. These interpretations, in principle, made it possible for a physician to commit euthanasia without becoming liable to punishment. ${ }^{3}$ In most cases that had gone to court, these interpretations had not led to a successful defence. The courts had either not accepted an exception to the prohibition of euthanasia, or ruled that euthanasia was not performed in a proper way, meeting specific standards. However, in one case, a court accepted a physician's defence, and this case was finally brought before the Supreme Court in $1984 .{ }^{4}$ In its first euthanasia case, the Supreme Court recognized that a physician can fulfil a patient's request to end his or her life. Given the careful way in which the physician involved made his decision and performed euthanasia, the court judged that he had made a reasonable choice under the circumstances. Although the physician had committed euthanasia, the court decided to acquit him. ${ }^{5}$ After this decision, the jurisprudence on euthanasia developed rapidly, and some general understanding arose about the conditions under which physicians would not be held liable to punishment. ${ }^{6}$

${ }^{2}$ Of course, the latter depends critically on the willingness of physicians to report a case of euthanasia to the public prosecutor.

${ }^{3}$ See the following court decisions: Rotterdam Court, 1 December 1981 (Nederlandse Jurisprudentie 1982: 63); Alkmaar Court, 10 May 1983 (Nederlandse Jurisprudentie 1983: 407); Amsterdam High Court, 17 November 1983 (Nederlandse Jurisprudentie 1984: 43); Groningen Court, 1 March 1984 (Nederlandse Jurisprudentie 1984: 450); Leeuwarden High Court, 11 October 1984 (Nederlandse Jurisprudentie 1985: 241). Previous court cases on euthanasia include: Utrecht Court, 11 March 1952 (Nederlandse Jurisprudentie 1952: 275); Leeuwarden Court, 21 February 1973 (Nederlandse Jurisprudentie 1973: 183).

${ }^{4}$ Supreme Court, 27 November 1984 (Nederlandse Jurisprudentie 1985: 106).

5 The Supreme Court formally based its decision on noodtoestand (emergency), which is based on the force majeure article of the Code of the Criminal Law (Article 40). Until then, the possibility of an appeal to an emergency situation had never been related to the issue of euthanasia.

${ }^{6}$ See the explanatory memorandum of the 1986 draft proposal for a bill, in which the cabinet summarizes the standards that were developed in the jurisprudence on euthanasia at that time (Kamerstukken II, 1985-86, 19.359, nr. 2). For the position of the Royal Dutch Medical Association (KNMG) on euthanasia, see 'Standpunt inzake euthanasie', Medisch Contact, 39 (1984), 990-8. 
In the second half of the 1980s the courts permitted euthanasia in certain well-specified circumstances. Meanwhile the political parties in parliament were unable to introduce new statutory regulations on euthanasia. By approving the 1993 bill the legislature in fact reconciled itself to the interpretation of the courts. The legislature's inability either to maintain the status quo, or to set a new statutory policy that would be supported by a majority in parliament, gives rise to several questions about the role of the courts in the political process. Why is it that the courts were able to give a new interpretation of the provisions on euthanasia in the Code of Criminal Law? Why was the legislature not successful in responding to these new interpretations by introducing a new statutory regulation that might have changed these interpretations? And to what extent has the lack of political consensus, particularly within the governing coalition, contributed to the development of a more liberal court interpretation of the ban on euthanasia? The purpose of this article is to analyse the impact of the courts in the Netherlands on the political decision-making process in the case of euthanasia.

The article is organized as follows. First, I discuss the main features of a parliamentary system that have to be taken into account in explaining legislative politics. Then I present a simple model of judicial-legislative interaction that builds on earlier work in the field of positive political theory. In this model courts have to decide whether or not they will give a new interpretation of a statute, which may trigger a legislative response that leads to the introduction of a new bill that sets aside the court's interpretation. By varying the assumptions about court behaviour, different hypotheses are derived about the outcome of decision making. In the next section the decision-making process on euthanasia is analysed in view of these hypotheses. In the final section I present my main conclusions on the role of courts in the euthanasia debate.

\section{PARLIAMENTARY POLITICS: CABINET AND COALITION PARTIES}

The parliamentary system in the Netherlands, in common with that of most countries in Western Europe, has a bicameral structure. ${ }^{7}$ The members of these chambers are selected in different ways, which may lead to members of each chamber holding different preferences. The members of the upper chamber, or Senate, are elected by the members of the Provincial Councils, who themselves are elected by voters. The members of the lower chamber, or House, are directly elected by voters. The House and the Senate have different formal powers in the legislative process. Members of the House are allowed to initiate legislation and amend a bill that is proposed by the cabinet. The Senate may only discuss a bill after it has been approved by the House. According to the Dutch

\footnotetext{
${ }^{7}$ See, for instance, G. Smith, Politics in Western Europe: A Comparative Analysis (London: Heinemann, 1976), for a review of political systems in Western Europe. The Dutch political system is discussed extensively in R. B. Andeweg and G. A. Irwin, Dutch Government and Politics (Basingstoke, Hants: Macmillan, 1993).
} 
Constitution, the Senate is not allowed to amend a bill, and it cannot bargain with the House when the opinions of the two bodies differ. ${ }^{8}$

Another important characteristic of the Dutch parliamentary system is that legislation is a joint effort between the cabinet and the House. This is a significant deviation from the doctrine of the separation of powers, which, for instance, forms the basis of the US presidential system. Both the cabinet and the House have the right to initiate legislation and both may introduce new legislation. In addition, both the House and the cabinet may block such initiatives. The House may decide not to approve a cabinet initiative, while the cabinet may reject a bill proposed by the House. The repudiation of a proposal initiated by the cabinet itself is regarded as unusual, since the cabinet and not parliament started the legislative process. In that case the cabinet is allowed to withdrawal the bill, which may even happen after the House has approved it. The only requirement is that the Senate has not yet made its decision. The underlying idea in this case is that the cabinet should have an opportunity to object to amendments by the House.

Most of the representatives elected to the Dutch parliament are members of a political party. As the result of strong party discipline, parties - rather than individual representatives - can be regarded as the relevant actors in the political decision-making process. ${ }^{9}$ In addition, none of these parties holds an absolute majority in parliament, which requires the formation of a coalition to share the powers of government. Consequently, the coalition parties, together with the cabinet, are much more important than the opposition in formulating and implementing public policies.

A governing coalition can be regarded as a voluntary agreement between the political parties represented in parliament. None of these parties can be forced to join a coalition. Only if all participants agree on various policy issues, as laid down in the coalition agreement, can a new cabinet be formed and formally invested. The voluntary nature of coalitions also implies that none of the coalition parties can prevent another party from abandoning its confidence in the cabinet. Consequently, policy making in this context has to be based on consensus within the governing coalition, that is, between the cabinet and the participating political parties as represented in the House and the Senate. If one of these players insists on introducing legislation, or supporting a proposal made by the opposition to which another player has severe objections, it may lead to a cabinet crisis and eventually to the fall of the government, or the dissolution

\footnotetext{
${ }^{8}$ The Senate may use the threat of a veto to amend a bill. A number of examples exist in which the Senate 'forces' the cabinet to introduce an amendment to a bill in the House. The discussion in the Senate is then adjourned in anticipation of the discussion of the amendment in the House. If the House accepts the amendment, the Senate will approve the original bill and the amendment, which will both become law. Since the original proposal will be (partially) replaced by the second one, this procedure provides the Senate with an indirect means of amending a legislative proposal.

9 See G. Brennan and H. Kliemt, 'Finite Lives and Social Institutions', Kyklos, 47 (1994), 551-71, for a game theoretical foundation for the emergence of political parties and the existence of party discipline.
} 
of parliament and new elections. So, in this respect, it is not clear whether the cabinet or parliament has the last word. The need to reach consensus within the governing coalition, including the cabinet, can be represented in terms of a veto for each participant. If a participant disagrees with a bill, it can use its veto to block the legislative discussion of, and finally the approval of, a bill. ${ }^{10}$

These 'informal' vetoes have shifted the emphasis in the legislative decision-making process from parliament to the cabinet. The cabinet, which is aware of the various preferences within the governing coalition, will not generally introduce a bill that will be unacceptable to one of the participating parties. Only if it is supported by all coalition members, and thus will avoid a veto, will the cabinet initiate legislation. Subsequently, the political debate in parliament does not generally lead to substantial changes in the initial cabinet proposal. The main reason for this is that these initiatives have already been discussed within the governing coalition.

JUDICIAL-LEGISLATIVE INTERACTION

\section{General Framework}

In my analysis of the Dutch debate on euthanasia I shall concentrate on the court review of statutory decisions, that is, policies that are laid down in formal legislation. New statutory interpretations can be the result of some ambiguity in the original provision, or the fact that, according to the judiciary, a statutory regulation violates some legal principle and needs to be modified. In the Netherlands, the courts, including the Supreme Court, are prohibited from testing statutory decisions according to their constitutional validity. So the fact that a statutory regulation violates a provision in the Constitution does not provide a ground for disregarding a regulation. For this reason, I make no distinction between constitutional and non-constitutional decisions of courts, as is done, for instance, by Spiller and Spitzer. ${ }^{11}$

I use a model in which the interpretation of a legislative regulation of the courts may trigger a legislative response: the passage of a bill. In the model, I distinguish three types of players: (1) the coalition parties represented in parliament; (2) the cabinet; and (3) the courts. The coalition parties in the House and the Senate are regarded as separate players, each having a veto on legislative initiatives. The cabinet and the courts are assumed to act as single players. ${ }^{12}$ Furthermore, and following the literature of positive political theory, courts are

\footnotetext{
${ }^{10}$ See also G. Tsebelis, 'Decision Making in Political Systems: Veto Players in Presidentialism, Parliamentarism, Multicameralism and Multipartism', British Journal of Political Science, 25 (1995), 289-325, for a characterization of political parties as veto players in a parliamentary setting.

${ }^{11}$ P. T. Spiller and M. L. Spitzer, 'Judicial Choice of Legal Doctrines', Journal of Law, Economics, and Organization, 8 (1992), 8-46.

${ }^{12}$ One may argue that different courts may not have the same preferences and therefore variations in the outcomes may exist. However, most judicial systems have a hierarchical structure to secure homogeneity in interpretation by the right of appeal. If appeal involves substantial transaction costs, variations in court interpretation may exist.
} 
not viewed as impartial arbiters, standing above the political process, but instead as political actors. ${ }^{13}$

I assume that the players will decide on the extent to which euthanasia should be permitted, which can be represented by a unidimensional outcome space $X=\mathbf{R}$. The preference of a player $i$ over $X$ is represented by a function $U_{i}=U_{i}(x)$, which defines single-peaked preferences. This implies that each player has a unique position on euthanasia; one that a player prefers most. This position is the player's ideal point. Moreover, the further away an alternative is from this ideal point, the less it is preferred. ${ }^{14}$ In addition, I assume that the cabinet's (induced) preference will be a point between the ideal points of the most extreme members of the governing coalition, since the formation of the cabinet is the result of bargaining among coalition parties. ${ }^{15}$

The players in the game are assumed to behave as politically sophisticated players, that is, they take into account the political consequences of their actions in subsequent stages of the game. Moreover, they are assumed to have complete and perfect information; that is, the preferences of players, the structure of the game, and the fact that players behave in a rational way, are assumed to be common knowledge, while only one player is allowed to make a move at every stage of the game. Furthermore, none of the players prefer their own decision to be overturned. This preference can be viewed as imposing some cost on a proposal that is not the final outcome of the decision-making process. ${ }^{16}$ These costs are assumed to reduce the final payoff to a player. If a unique equilibrium outcome exists, which can be reached either by proposing this outcome or by having another player reverse its decision and proposing the final outcome, a player will prefer the first alternative.

The decision-making process will be taken as a sequential game with the following stages. In the first stage, the courts, which are confronted with a case, have to decide whether or not they will give a new interpretation of an existing

${ }^{13}$ See, for instance, the following contributions to this literature: R. Gely and P. T. Spiller, 'A Rational Choice Theory of Supreme Court Statutory Decisions with Applications to the State Farm and Grove City Cases', Journal of Law, Economics, and Organization, 6 (1990), 263-300; J. Ferejohn and C. Shipan, 'Congressional Influence on Bureaucracy', Journal of Law, Economics, and Organization, 6 (1990) (Special Issue), S1-20; P. T. Spiller and R. Gely, 'Congressional Control or Judicial Independence: The Determinants of US Supreme Court Labor-Relations Decisions, 1949-1988', Rand Journal of Economics, 23 (1992), 463-92; Spiller and Spitzer, 'Judicial Choice of Legal Doctrines'; W. N. Eskridge and J. Ferejohn, 'Making the Deal Stick: Enforcing the Original Constitutional Structure of Lawmaking in the Modern Regulatory State', Journal of Law, Economics, and Organization, 8 (1992), 165-89; J. A. Ferejohn and B. R. Weingast, 'A Positive Theory of Statutory Interpretation', International Review of Law and Economics, 12 (1992), 263-79; R. Gely and P. T. Spiller, 'The Political Economy of Supreme Court Constitutional Decisions: The Case of Roosevelt's Court-Packing Plan', International Review of Law and Economics, 12 (1992), 45-67; and L. Cohen and M. L. Spitzer, 'Solving the Chevron Puzzle', Law and Contemporary Problems, 57 (1994), 67-110.

${ }^{14}$ For an introduction to spatial modelling, see J. M. Enelow and M. J. Hinich, The Spatial Theory of Voting: An Introduction (Cambridge: Cambridge University Press, 1984).

15 That is, $v_{l}<c<v_{r}$, with $v_{l}=\min \left\{v_{i}\right\}$ and $v_{r}=\max \left\{v_{i}\right\}$ for all $v_{i} \in V, V=\left\{\mathrm{v}_{l}, v_{2}, \ldots v_{v}\right\}$, with $v_{i}$ as the ideal point for coalition party $i$, and $c$ as the ideal point of the cabinet.

${ }^{16}$ See also Ferejohn and Shipan, 'Congressional Influence on Bureaucracy', p. 6. 
statute. This statutory provision is exogenously given. The legislature may respond to a new interpretation of the current statute by enacting a new one. As indicated, both the cabinet and the House have the right of initiative. However, in practice, the cabinet initiates nearly all legislation. It is rare for a bill to be proposed by one of the parties in parliament. This emphasis on cabinet initiatives can be explained by the costs of drafting a bill and the veto power of the cabinet and the coalition parties. In the model, I therefore assume that the cabinet, as the key actor in the governing coalition, will take the initiative and propose a new bill. Subsequently, this proposal will be considered by the coalition parties in the House and the Senate for approval. If these parties agree - i.e., if they do not veto the bill - the proposal will be enacted.

Using this sequence of play, a new interpretation by the courts forms the basis of the decision-making process in the legislature. In other words, the court's interpretation of the statute has to be regarded as the starting point for legislative initiative. An interpretation remains unchanged unless the legislature introduces and approves a new bill. So the course of action initiated by the courts has to be considered as the point from which the legislature may propose a change. This provides the courts with an important first-move advantage.

\section{Politically Viable Interpretations}

Before I turn to the courts' decision, I will discuss the legislature's passage of a bill as a response to a new statutory interpretation by the courts. Assume that the cabinet, as a response to the courts, proposes a new bill. This proposal will be considered by the coalition partners in parliament. If one of the coalition parties objects to this proposal and uses its veto, the outcome of the decision-making process will be the court interpretation. So, in order to have its proposal approved, the cabinet is induced to select a bill from the set of proposals that will not be vetoed by any of the veto players. Since a player will only veto those bills that are less preferable than the status quo, the set of bills that will not be vetoed is equivalent to the intersection of the preference sets of the veto players. This intersection will be called the set of politically feasible bills, since it contains those bills that will be accepted by the veto players in the legislative process. ${ }^{17}$

The cabinet is induced to select a proposal from the feasible set if it prefers to change the statutory interpretation of the courts. If the feasible set is not empty, proposals exist which are preferred to the statutory interpretation by all veto players and thus will not be vetoed. In that case, the cabinet will start a legislative process leading to a new statute. However, if the feasible set is empty, legislative action is not politically feasible since any proposal will be vetoed. This implies that the statutory interpretation is invulnerable to legislative

${ }^{17}$ Let $R_{i}$ be the preference set of a player $i$, that is, the set of points a player (weakly) prefers to $q$. This set is defined as $R_{i}=\left\{x \mid U_{i}(x) \geqslant U_{i}(q), x \neq q\right\}$, with $q \in X$ as the current statutory provision or status quo ante (or simply, status quo). The set of feasible bills can now be defined as $R_{v}=\bigcap_{i} R_{v_{i}}(x)$, for all veto players $v_{i} \in V$. 
change. From the definition of the preference set and the assumption of single-peaked preferences, it follows directly that the feasible set is empty if and only if the statutory interpretation is equivalent to the ideal points of one of the most extreme coalition parties, or any point between the most extreme two players. ${ }^{18}$ The points that fulfil this condition and thus will not lead to a legislative response, are called the set of politically viable interpretations. ${ }^{19}$

\section{Court Preferences and Equilibrium Outcomes}

The problem that sophisticated courts face is to select a statutory interpretation that results in an empty set of politically feasible bills. The courts' choice of a point within this set depends on their preferences. The literature on court behaviour is divided about the preferences that courts may have. At this point two different views can be distinguished. The first view is that the courts have substantive policy preferences and behave as constrained policy advocates, as most models assume. In this view, the courts, like any other political player, have well-defined policy preferences, and they try to impose their preferences by giving a new and divergent statutory interpretation. ${ }^{20}$ The second view is that courts only have originalist preferences and behave as conservers (that is, sophisticated textualists or intentionalists). ${ }^{21}$ Courts are not so much interested in setting a new policy, but in maintaining the original legislation or legislative intentions. ${ }^{22}$ In a unidimensional model, this type of preference can be specified in such a way that courts take the status quo as the starting point for their interpretations, or select an interpretation that best fits the original intentions of the enacting legislature. ${ }^{23}$ Furthermore, the courts do take account of the

${ }^{18}$ See B. Steunenberg, 'Regulatory Policymaking in a Parliamentary Setting', in P. HerderDorneich, K-E. Schenk and D. Schmidtchen, eds, Jahrbuch für Neue Politische Ökonomie: Neue Politische Ökonomie der Regulierung, Deregulierung und Privatisierung (Tübingen: Mohr, 1994), pp. 36-57, at pp. 42-3, for a similar result.

${ }_{19}$ Formally, the set of politically viable interpretations can be defined as $S=\left\{x \mid R_{v}=\phi\right\}$. Note that this set is equivalent to the interval $\left[v_{l}, v_{r}\right]$.

${ }^{20}$ See, for instance, Gely and Spiller, "A Rational Choice Theory of Supreme Court Statutory Decisions with Applications to the State Farm and Grove City Cases'; Ferejohn and Shipan, 'Congressional Influence on Bureaucracy'; and Spiller and Spitzer, 'Judicial Choice of Legal Doctrines'.

${ }^{21}$ Ferejohn and Weingast, 'A Positive Theory of Statutory Interpretation'.

22 An alternative view is suggested by S. Rose-Ackerman, 'Comment on Ferejohn and Shipan's "Congressional Influence on Bureaucracy"', Journal of Law, Economics, and Organization, 6 (1990) (Special Issue), S21-7, who argues that courts are not so much interested in the policy outcomes but in the procedural principles that are used to derive a particular outcome. This view implies a multidimensional model in which a policy as well as a procedural dimension play a role. An example of such a model is found in L. Cohen and M. L. Spitzer, 'Solving the Chevron Puzzle'.

${ }^{23}$ In this article I will not distinguish between a textualist interpretation, that is, an interpretation as close as possible to the text of the statutory regulation, and an intentionalist interpretation, that is, one as close as possible to the intentions of the enacting legislature. The model used in the article does not allow for differences between the intentions or preferences of a governing coalition and the outcome that will be enacted. Both interpretations therefore point to the status quo ante. See K. A. Shepsle, 'Congress Is a "They", Not an "It": Legislative Intent as Oxymoron', International Review of Law and Economics, 12 (1992), 239-56, for a critique of the textualist-intentionalist position. 
political consequences of their decisions. In other words, they present statutory interpretations that are also acceptable to the current legislature.

Both assumptions about court preferences will be used in this article to derive alternative hypotheses about the outcome of judicial-legislative interaction. If the courts behave as policy advocates, they will select a new statutory interpretation that will not be reversed by the legislature and is as close as possible to their ideal point. The legislature will introduce and enact a new bill to reverse the courts' decisions, if the new statutory interpretation is not a politically viable interpretation. Given this response, the courts will select a point from the set of viable interpretations they prefer most. Given singlepeaked preferences, it follows directly that the equilibrium outcome is equivalent to the ideal point of one of the extreme coalition parties, or any point between these two parties, which the courts prefer most. ${ }^{24}$ Statutory interpretations will be restricted to politically viable interpretations, but vary with the courts' policy preferences. This leads to the following hypothesis with regard to the outcome of judicial-legislative interaction:

Hypothesis 1 (policy advocate hypothesis). If the courts behave as policy advocates, the statutory interpretation of the courts is found between the policy positions of the most extreme coalition parties, and is equivalent to, or as close as possible to, the preference of the courts.

Courts, behaving as conservers, do not have well-defined policy preferences of their own, but instead prefer to maintain the status quo as long as this is politically feasible. If the courts behave in this way, they will only select a new statutory interpretation if the current one is no longer politically viable. Knowing the response of the legislature, the courts' problem now is to find a politically viable interpretation that is as close as possible to the status quo. ${ }^{25}$ The equilibrium outcome for this game is equivalent to the status quo if it is found between the ideal points of the most extreme coalition parties, or the ideal point of one of the most extreme parties that is closest to the status quo if the status quo is not found between the ideal points of both extreme parties. ${ }^{26}$ Statutory interpretations are again restricted to politically viable interpretations, but now vary with the status quo. This leads to the following alternative hypothesis for judicial-legislative interaction:

\footnotetext{
${ }^{24}$ Formally, the equilibrium outcome is the following court interpretation, $x$ : (i) $x=v_{l}$ for $j<v_{l}$, (ii) $x=j$ for $j \geqslant v_{l}$ and $j \leqslant v_{r}$, or (iii) $x=v_{r}$ for $j>v_{r}$, with $j$ as the ideal point of the courts, and $v_{l}$ and $v_{r}$ as the ideal points of the leftmost and rightmost coalition party, respectively.

${ }^{25}$ If courts behave as naive players, they will select the status quo (courts as conservers) or their ideal point (courts as policy advocates) as the statutory interpretation. If the status quo or the courts' ideal point is found outside the set of politically viable interpretations, the legislature can explicitly take on the issue if it wishes.

${ }^{26}$ Formally, the equilibrium outcome is the following court interpretation, $x$ : (i) $x=v_{l}$ for $q<v_{l}$; (ii) $x=q$ for $q \geqslant v_{l}$ and $q \leqslant v_{r}$; or (iii) $x=v_{r}$ for $q>v_{r}$, with $q$ as the status quo, and $v_{l}$ and $v_{r}$ as the ideal points of the leftmost and rightmost coalition party, respectively.
} 
Hypothesis 2 (conserver hypothesis). If the courts behave as conservers, the statutory interpretation of the courts is found between the policy positions of the most extreme coalition parties, and is equivalent to, or as close as possible to, the status quo.

Both hypotheses predict outcomes that differ in most instances, but not all. Different equilibrium interpretations are found in the following two cases:

(1) When the status quo and the courts' ideal point are found outside the set of politically viable interpretations and at different sides of the governing coalition. Then, a court that behaves as a policy advocate will select the policy position of the rightmost coalition party as the equilibrium interpretation, while a conserver chooses the policy position of the leftmost coalition party, or vice versa.

(2) When the status quo is found in the set of viable interpretations, while the ideal point of a policy advocate is not equivalent to the status quo. A conserver will not present a new statutory interpretation and adheres to the current statute. A policy advocate, however, will come up with a new interpretation that diverges from the current statute. ${ }^{27}$

For these two cases, it is possible to discriminate empirically between both competing models and to assess the extent to which each hypothesis best predicts the outcome that is found for the debate on euthanasia. Similar equilibrium interpretations are predicted when the status quo and the policy advocate's ideal point are both outside the set of viable interpretations and on the same side as one of the extreme coalition members. ${ }^{28}$ In such cases, the equilibrium interpretations will be equivalent to the policy position of the leftmost or the rightmost coalition party, and it is not possible to differentiate empirically between the two models of court behaviour.

THE POLITICS OF EUTHANASIA

Parliamentary Debate ${ }^{29}$

In 1978, a majority in parliament supported a motion in which the cabinet was asked to form a special committee to obtain advice about future policies on

\footnotetext{
${ }^{27}$ Note that only in the exceptional case that $j=q$ will a policy advocate not give a new statutory interpretation.

${ }^{28}$ That is, $j<v_{l}$ and $q<v_{l}$, or $j>v_{r}$ and $q>v_{r}$.

${ }^{29}$ For other accounts of the euthanasia debate in the Netherlands, see J. K. M. Gevers, 'Legal Developments Concerning Active Euthanasia on Request in the Netherlands', Bioethics, 1 (1987), 156-62; B. Sluyters, 'Euthanasia in the Netherlands', Medico-Legal Journal, 57 (1989), 34-43; and H. A. M. J. ten Have and J. V. M. Welie, 'Euthanasia: Normal Medical Practice?' Hastings Center Report, 22 (1992), 34-8.
} 
euthanasia. This motion can be regarded as the start of the euthanasia debate. ${ }^{30}$ In subsequent years, euthanasia became an important political issue, partly because the courts developed a jurisprudence that deviated from the common view at that time, that euthanasia was a criminal offence. The new jurisprudence started in 1981 with a ruling of the court in Rotterdam. In its decision, the court pointed to a number of standards with which a physician had to comply in performing euthanasia. Shortly after this court ruling, the minister of justice changed the prosecution policy on euthanasia. He insisted that all euthanasia cases had to be discussed in meetings of attorneys-general, who direct prosecution policies in the five judicial districts of the Netherlands. In these meetings, the attorneys-general would have to decide whether or not a physician would be prosecuted. This arrangement guarantees that the prosecution would not differ among jurisdictions. Furthermore, in the period 1982-94, the Public Prosecutor's Office followed the standards on euthanasia that were developed by the courts. ${ }^{31}$

In 1984, just before the Supreme Court's first decision on euthanasia, one of the opposition parties, the Democrats '66 (D66), submitted a bill on euthanasia to parliament. In this bill, D66 proposed to legalize euthanasia in those cases in which a patient, who was facing unbearable suffering without the possibility of any further treatment, asked a physician to end his or her life. The bill aimed to change the Code of Criminal Law so that a physician who performed euthanasia would no longer be prosecuted. The cabinet then awaited the advice of the special committee on euthanasia, which issued its report in the summer of 1985. Finally, in early 1986, the cabinet responded to the report and the D66 initiative. The cabinet's statement was that new legislation was not necessary. However, if parliament wanted to introduce new legislation, then the cabinet would prefer a bill that was in line with a draft proposal for a bill, which was sent along with the statement. ${ }^{32}$ This proposal, which was not a bill, also aimed to change the Code of Criminal Law. However, compared with the opposition proposal, the cabinet proposal was more restrictive. First, euthanasia in general

\footnotetext{
30 This debate occurred after a period in which the opinions of voters on this issue changed significantly. In 1966, 49 per cent of the population strongly objected to euthanasia and regarded it as a serious criminal offence. By 1975, only 24 per cent opposed euthanasia, and by 1991 this figure had dropped to 9 per cent. From the mid-1970s on, a majority of voters thought that euthanasia should be permitted. By 1991, 58 per cent held this view. Another 33 per cent of voters did not completely object to euthanasia, but indicated that euthanasia should only be permitted under particular circumstances. See the Social and Cultural Planning Office, Social and Cultural Report 1988 (Alphen aan den Rijn: Samsom, 1988), Chapter 11, and the Social and Cultural Planning Office, Social and Cultural Report 1992 (The Hague: VUGA, 1992), Chapter 11.

${ }^{31}$ Based on parliamentary questions to government, only one deviation appears to have occurred in this period. In 1993-94 the minister of justice, a member of the Christian Democrats, insisted that cases in which a physician performed euthanasia on patients when it was not clear that they would soon die as a result of illness, were to be prosecuted. According to jurisprudence, this standard is not (and was not then) a relevant criterion in assessing a physician's liability to punishment.

${ }^{32}$ The proposal of the cabinet did not yet have the status of a bill, but it could become a bill in the near future.
} 
would remain a criminal offence. Only when specific standards were met would a physician escape legal liability. Secondly, the proposal restricted the practice of euthanasia to cases in which a patient 'suffers unbearably as a result of an illness and whose death is to be expected'. This implies that euthanasia is not permitted if the suffering of the patient is not unbearable, not of a physical nature, or the illness is not expected to lead to the patient's death.

The cabinet's statement on euthanasia came shortly before the 1986 elections. After these elections, a new cabinet was again formed between the Christian Democrats and the Liberal party. These parties opposed one another on euthanasia. Nevertheless, in December 1987, the cabinet introduced a new bill which proposed to change the Code on the Medical Profession. Based on this proposal, the Code would include standards with which a physician had to comply in performing euthanasia. The bill did not change the Code of Criminal Law. A physician would still be held accountable for committing euthanasia, even if he or she followed the proposed standards. In the cabinet's view, a court still had to decide whether or not a physician was to be held liable to punishment. Therefore, with the introduction of this bill, the cabinet began to move away from an effort to change the Code of Criminal Law and towards a solution that relied solely on the existing jurisprudence.

In 1989, in the period in which the cabinet proposal and the opposition proposal were discussed in parliament, a cabinet crisis arose on a different matter and the government fell. In the same year, general elections were held, and a new cabinet came to office in the autumn. This cabinet was based on a coalition between the Christian Democrats and the Labour party. Both parties agreed to adjourn the parliamentary debate on the bill proposed by the preceding cabinet. A committee was established to survey the practice of euthanasia by physicians. At the end of 1991, the cabinet indicated that it would like to improve the assessment of physicians who commit euthanasia by changing the procedures that were laid down in the Code on the Disposal of Bodies. ${ }^{33}$ After parliamentary debate, in which the coalition parties supported this position, the cabinet withdrew the 1987 proposal and introduced a new bill. As indicated in the introductory section of this article, this bill conferred on the two ministers most closely involved the power to set standards about the way in which a physician has to report a case of euthanasia to the public prosecutor. Finally, the bill was adopted by parliament at the end of 1993.

\section{Party Positions and Cabinet Government}

The policy positions of political parties can be derived from the party manifestos, which are published before the elections. ${ }^{34}$ As indicated in these manifestos, the political parties in parliament appear to be divided over

\footnotetext{
33 This code regulates the disposing of a body once a person has died.

${ }^{34}$ For the elections in 1981, 1986 and 1989, these manifestos are compiled in I. Lipschits, Verkiezingsprogramma's 1981 (The Hague: Staatsuitgeverij, 1981); I. Lipschits, Verkiezings-
} 
euthanasia. On the one hand, parties such as the Christian Democrats and the smaller Political Reformed Party (SGP) and Reformed Political League (GPV), reject legalization of euthanasia and insist on the maintenance of euthanasia as a criminal offence. These parties stressed the importance of an effective protection of life. Individuals cannot freely dispose of their life, which is a gift of God. The only reason for new legislation, in the view of these parties, is to reconfirm the status quo. The Christian Democrats, for instance, indicated in their 1986 manifesto that legislation might be necessary to clarify the definition of euthanasia. A patient's refusal of a medical treatment in general, or a medical treatment that aimed to reduce a patient's suffering but had an unintended life-shortening effect, should not be regarded as euthanasia. Euthanasia itself i.e. the ending of a person's life with his or her consent - should remain a criminal offence. On the other hand, the Labour party, the Liberal party, D66 and Green Left preferred a statutory regulation in which euthanasia was permitted under well-specified circumstances. These parties do not have substantially different views, although D66 seems to hold a more liberal position than the Liberals or the Labour party by stressing the individual's right of self-determination and by putting less emphasis on the conditions under which a physician may comply with a patient's request. In general the dividing line between the political parties in parliament seems to be primarily based on their views on individual self-determination. Emphasizing the protection of life, the Christian parties in parliament object to any change in the current ban on euthanasia. Favouring freedom of individual choice, the other, non-religious, parties would like to have a statutory regulation that allows physicians to carry out some of the euthanasia requests they receive. ${ }^{35}$

Additional evidence on the policy positions of the various political parties represented in parliament comes from an extensive study in 1990, which surveyed all members of the House and the Senate. One of the questions in this survey dealt with euthanasia. The members of parliament were asked to give their party position on euthanasia using a seven-point scale, which varied from maintaining the ban on euthanasia to permitting a physician to end a person's life with his or her consent. The results of this survey for the members of the

(F'note continued)

programma's 1986 (The Hague: Staatsuitgeverij, 1986); and I. Lipschits, Verkiezingsprogramma's 1989 (The Hague: Staatsuitgeverij, 1989).

35 In 1991 an extensive study estimated the extent to which euthanasia occurs in the Netherlands. This study indicated that, annually, about 2,300 persons die as a result of euthanasia. In about 1,400 cases a physician performs euthanasia; in about 400 cases a physician assists the patient in committing suicide. By contrast, it was also estimated that physicians receive about 9,000 euthanasia requests from patients annually. See P. J. van der Maas, J. J. M. van Delden and L. Pijnenborg, Medische beslissingen rond het levenseinde: het onderzoek voor de Commissie onderzoek medische praktijk inzake euthanasie (The Hague: SDU, 1991); and P. J. van der Maas, J. J. M. van Delden, L. Pijnenborg and C. W. N. Looman, 'Euthanasia and Other Medical Decisions Concerning the End of Life', The Lancet, 338 (1991), 669-74. 
a. Party positions in the House

\begin{tabular}{|c|c|c|c|c|c|c|c|}
\hline \multirow{2}{*}{ no ban $\begin{array}{r}1 \\
+\end{array}$} & 1.8 & 1.9 & 2 & 2.6 & 5 & 5.8 & \multirow{2}{*}{$\begin{array}{l}7 \\
+ \text { ban } \\
/ \text { GPV/RPF }\end{array}$} \\
\hline & & & & Liberals & CD & CDA & \\
\hline
\end{tabular}

b. Party positions in the Senate

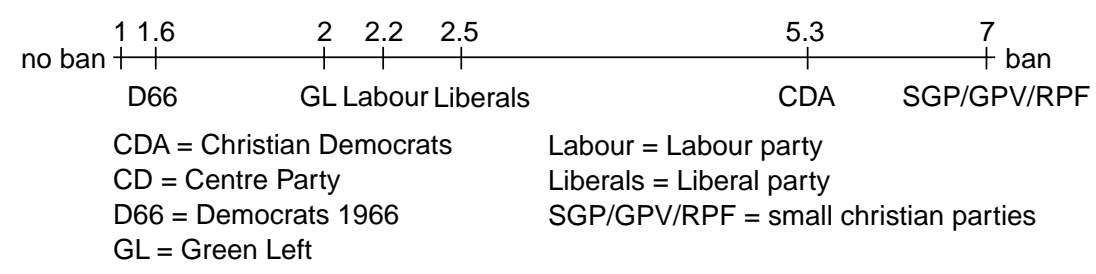

Fig. 1. Policy positions of political parties on euthanasia: average score on a seven-point scale Note: The data on party positions used in this diagram were kindly provided by Jacques Thomassen, University of Twente, and are based on the 1990 survey of the members of the Dutch parliament. I rescaled the relevant variable so that the rightmost position corresponds with a preference for the continuation of the legal ban on euthanasia (highest score).

House and the Senate are given in Figure $1 .{ }^{36}$ As the diagram shows, the political parties in parliament were divided. As was also indicated by the party manifestos, the Christian Democrats held a rather conservative view on euthanasia. Other parties with a substantial share of the vote, such as the Labour party and the Liberal party, maintained a much more liberal position, as did D66. These parties controlled about 60 per cent of the votes in parliament. In other words, a substantial majority existed in favour of a more progressive statutory regulation on euthanasia. Nevertheless, parliament did not approve legislation to change the Criminal Code, but settled on an administrative solution about the way in which a physician has to report a case of euthanasia to the Public Prosecutor's Office.

The reason why parliament was not able to approve a liberal statutory regulation on euthanasia is the domination by the Christian Democrats of the various governing coalitions in the 1980s. Table 1 presents the cabinet governments in this period, the party affiliation of the prime minister and the participating coalition parties. The Christian Democrats participated in all the succeeding governing coalitions. In addition, the Christian Democrats, as the largest political party, also took the lead in the cabinet formations during this

${ }^{36}$ The members of parliament were also asked to give their own opinions on euthanasia. These answers did not lead to an ordering of political parties that differs from the results for the question on party positions, with two exceptions: first, the members of Green Left assessed their party position (average score 1.9) as being more liberal than their own views (average score 2.6). Second, it appears that the views of the members of D66 in the House are similar to those of the members of the Labour party (average score 2.1), while the assessed party positions differ slightly (average score for D66 1.9, and 2.0 for the Labour party). 
TABLE 1 Cabinet Governments and Coalition Parties, 1977-94

\begin{tabular}{lll}
\hline \hline & $\begin{array}{c}\text { Party } \\
\text { affiliation } \\
\text { of prime } \\
\text { minister }\end{array}$ & Participating parties* \\
\hline 1977-81 Van Agt I & CDA & CDA (33) - Liberal Party (19) \\
1981-82 Van Agt II & CDA & CDA (32) - Labour Party (29) - D66 (11) \\
1982 Van Agt III & CDA & CDA - D66† \\
1982-86 Lubbers I & CDA & CDA (30) - Liberal Party (24) \\
1986-89 Lubbers II & CDA & CDA (36) - Liberal Party (18) \\
1989-94 Lubbers III & CDA & CDA (36) - Labour Party (33) \\
\hline \hline
\end{tabular}

*Percentage vote share of the party in the House between parentheses.

$\dagger$ Minority cabinet for about five months until the formation of a new cabinet after the snap elections in September 1982. The Van Agt II cabinet fell on 29 May 1982.

period and nominated the prime minister. As a coalition member, they were able to prevent any initiative from becoming law. During their membership of the governing coalition, both the Liberal party and the Labour party conformed with their coalition partner and did not support any opposition initiative. ${ }^{37}$ Otherwise, the governing coalition, which agreed on a whole range of other issues, would fall. The Liberals and Labour, for instance, did not support the D66 bill, which was submitted to parliament in 1984. They preferred the continuation of the current governing coalition to their own position on euthanasia. For this reason, the majority in parliament that supported the 1993 bill (i.e., the Christian Democrats and the Labour Party) would have differed from the parliamentary majority, had it been able to vote on a free basis.

The 1993 bill can be regarded as a successful attempt to remove euthanasia from the political agenda in a way that secured the interests of the Christian Democrats. The bill obliges physicians to report euthanasia to the prosecution, while euthanasia itself remains a criminal offence. The Labour party, which was the coalition partner at that time, had a much more liberal preference on euthanasia. It would have preferred to legalize euthanasia on the basis of a statutory regulation. In early 1993, when the D66 bill was put to a vote, the Labour party, whose position greatly resembled that of D66, voted against. As a member of the governing coalition, it supported the cabinet proposal and did not want to cause a cabinet crisis. The cabinet proposal was accepted and not the D66 bill. The cabinet proposal did not legalize euthanasia in the sense that the Code of Criminal Law was modified. However, neither did it override the existing jurisprudence in favour of a more restrictive regulation. By accepting

\footnotetext{
${ }^{37}$ Note that for the same reason, neither the Liberal party nor the Labour party could unilaterally propose a new bill on euthanasia.
} 
this proposal, the coalition parties in fact reconciled themselves to the current state of affairs in which the courts determine the admissibility of euthanasia.

The set of politically viable interpretations can be based on the policy positions of political parties as derived from their party manifestos, and supported with data from the 1990 survey of members of parliament. As indicated, this set consists of all those points that are found between the policy positions of the most extreme coalition parties. For the period 1982-89, in which there were two governments, each consisting of Christian Democrats and Liberals, the most extreme policy positions were held by these two parties. For 1989-94, the set of viable interpretations was determined by the policy positions of the Christian Democrats and the Labour party.

\section{The Role of the Supreme Court}

Before the role of the Supreme Court is analysed, two additional questions need to be addressed. First, where the status quo is located along the policy dimension, and, secondly, which preference does the Supreme Court hold, if courts behave according to the policy advocate hypothesis. The status quo is the current provision in the Code of Criminal Law, which indicates that euthanasia is a criminal offence carrying a maximum sentence of twelve years' imprisonment or a substantial fine. ${ }^{38}$ This point corresponds to the policy positions of the Christian Democrats and the smaller Christian parties, which explicitly object to any change in the current provisions of the Code of Criminal Law. In this analysis I will therefore take the status quo to be equal to the ideal point of the Christian Democrats in Figure 1, or to be located to the right of their policy position.

The party affiliation of the members of the Supreme Court is not known: I therefore have to follow an indirect route to determine their preferences, which can be based on the way the judges are selected. The members of the Supreme Court are appointed by the cabinet. ${ }^{39}$ This appointment is drawn from a list of three candidates, which is submitted to the government by the House. If a vacancy occurs, the Supreme Court may suggest up to six candidates, but the House is not obliged to select any of these persons. It may select candidates that are not mentioned, or reverse the order of the persons listed. ${ }^{40}$ Although the House normally adopts the suggested candidates, this does not imply that the House has no influence. It may very well be the case that the Supreme Court anticipates the preferences of the main parties in the House to avoid House intervention. In fact, if the appointment process is modelled as a sequential game

\footnotetext{
${ }^{38}$ For assisted suicide the maximum penalty is three years' imprisonment.

39 Formally, the appointment of members to the Supreme Court is made by the Crown. Since the cabinet, as the government's decision-making body, is politically responsible for all government actions, including the acts of the monarch, I prefer to use the term cabinet.

${ }^{40}$ In contrast to US procedure, the House does not start a formal inquiry on the proposed candidates.
} 
of complete and perfect information in which the Supreme Court moves first, and the House last, a change of the Supreme Court's list of candidates will never occur, while the proposed candidates correspond to the preferences in the House. Given the various cabinets formed in the 1970s and 1980s between the Christian Democrats, the Labour party, and the Liberals, the preference of the Supreme Court is expected to be found between the most extreme policy positions of these three parties. In other words, the Supreme Court's ideal point has to be located to the left of the policy position of the Christian Democrats. It is not located at the Christian Democrats' position, or to their right. Furthermore, since the Christian Democrats participated in all governing coalitions during this period, it is also unlikely that the Supreme Court's ideal point is to be found near the other extreme, that is, the policy position of the Labour party.

Supreme Court preferences have to be distinguished from the equilibrium outcome, although both may empirically coincide when the court is able to select its most preferred point as the equilibrium interpretation. In its 1984 decision, the Supreme Court argued that a euthanasia request may confront a physician with an important conflict of duties. A physician has to provide medical care and to save life, on the one hand. On the other hand, he also has to take account of his patient's suffering and wish to die. If the patient's condition is intolerable, a physician may chose to perform euthanasia when he considers the conflicting duties carefully. Although it is very difficult to formulate general guidelines for a choice under these circumstances, the court decision points to a number of conditions that, at a minimum, need to be satisfied for a successful appeal. The most important conditions are that: (1) the patient's illness is irreversible and not expected to improve, while meaningful alternative treatments are not available; (2) the patient has a lasting wish to die; (3) the patient's illness leads to unbearable suffering; and (4) euthanasia has to be performed by a physician. These conditions recurred in the Supreme Court decisions in 1986 and $1987 .{ }^{41}$ This new interpretation, which was developed in the period 1984-87, to some extent resembles the policy positions of the Liberals and the Labour party. In their party manifestos, both the Liberal party and the Labour party stressed the voluntary nature of euthanasia, the last wish of the patient to die, and the utmost care in deciding on the patient's euthanasia request, as important elements for new statutory regulation. ${ }^{42}$ These elements are reflected in the conditions that

${ }^{41}$ See Supreme Court, 21 October 1986 (Nederlandse Jurisprudentie 1987: 607), and Supreme Court, 23 June 1987 (Nederlandse Jurisprudentie 1988: 157). In the period 1984-93, the Supreme Court gave its opinion on euthanasia in four other cases. See: Supreme Court, 15 December 1987 (Nederlandse Jurisprudentie 1988: 811); Supreme Court, 3 May 1988 (Nederlandse Jurisprudentie 1989: 391); Supreme Court, 28 April 1989 (Nederlandse Jurisprudentie 1990: 46, 47); and Supreme Court, 28 May 1991 (Nederlandse Jurisprudentie 1991: 789).

${ }^{42}$ See the 1986 and 1989 party manifestos for the Liberal party, Lipschits, Verkiezingsprogramma's 1986, pp. 439, 468, and Lipschits, Verkiezingsprogramma's 1989, p. 63. For the Labour party, see Lipschits, Verkiezingsprogramma's 1986, p. 304, and Lipschits, Verkiezingsprogramma's 1989, p. 249. 


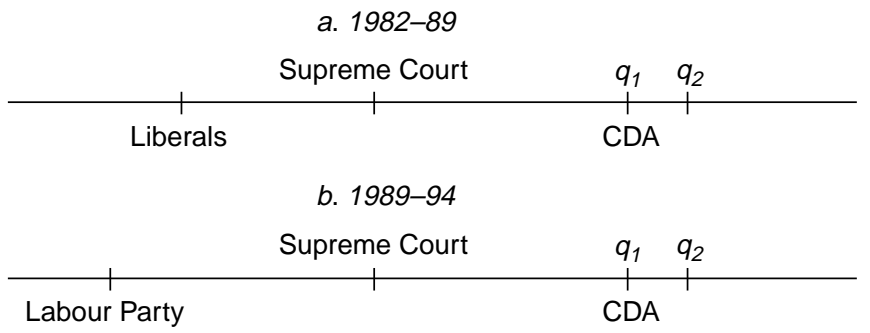

Fig. 2. Relevant player positions and statutory interpretation on euthanasia

were formulated in the jurisprudence. The Christian Democrats, however, strongly opposed a regulation that would permit a physician to end a patient's life. ${ }^{43}$ So the new interpretation that was developed is by no means identical to the position of the Christian Democrats. Moreover, the Supreme Court's interpretation clearly deviates from the existing ban on euthanasia as expressed by the Code of Criminal Law.

The positions of the relevant players for the period 1982-89 and 1989-94 are given in Figure 2. The ideal point of the Supreme Court is, for the time being, located between the Christian Democrats and the Liberals. The policy dimension varies from maintaining, or even reinforcing, a ban on euthanasia (right), to legalizing euthanasia completely (left). Since the status quo was positioned equal to or to the right of the policy position of the Christian Democrats (CDA), I distinguish two versions of this point, which are labelled $q_{1}$ and $q_{2}$, respectively. Following the conserver hypothesis, the courts will select a statutory interpretation that will be as close as possible to the status quo. If the status quo is equivalent to $q_{1}$, there is no need for a new statutory interpretation, since the current provision still lies within the set of politically viable interpretations. This clearly contradicts the empirical observation that points to a change of the statutory interpretation towards a more liberal view of euthanasia.

If, however, the status quo has to be associated with a point like $q_{2}$ in the diagram, a minor change will be perceived, but the new statutory interpretation will be similar to the view of the Christian Democrats. Although the conserver hypothesis now explains the fact that the statutory interpretation changed in the Netherlands, it does not point to the correct outcome. The Christian Democrats, who were prepared to exclude some medical decisions from their definition of euthanasia, prefer to maintain a ban on euthanasia and to enforce this ban under the Code of Criminal Law. ${ }^{44}$ The jurisprudence that developed in the second half of the 1980s, starting with the Supreme Court decision in 1984, yields a much

43 See the 1986 and 1989 party manifestos of the Christian Democrats, Lipschits, Verkiezingsprogramma's 1986, pp. 18-19, and Lipschits, Verkiezingsprogramma's 1989, pp. 381, 430.

${ }^{44}$ Medical decisions, which the Christian Democrats do not regard as euthanasia, as is indicated in their party manifestos for the 1986 and the 1989 elections, include: the suspension of a treatment of a patient who has lost consciousness in an irrevocable way; and death as an unintended result of 
more liberal view, in the sense that a physician who performs euthanasia will not be held liable to punishment under some well-specified circumstances. While the conserver hypothesis predicts an outcome equivalent to the position held by the Christian Democrats, the actual outcome is a point to the left of this position and close to the views of the Liberals and the Labour party. This outcome of the euthanasia debate fails to support the conserver hypothesis.

The policy advocate hypothesis points to a different outcome. According to this hypothesis, the Supreme Court selects a politically viable interpretation as close as possible to its own ideal point. The Supreme Court's ideal point is located to the left of the ideal point of the Christian Democrats. This would imply that: (a) when a case on euthanasia is brought before the Supreme Court, the Court will select an interpretation that differs from the status quo, and (b) this new interpretation will be equivalent, or as close as possible, to the Supreme Court's ideal point. ${ }^{45}$ The change in interpretation that occurred in the $1980 \mathrm{~s}$ seems to be in line with this hypothesis. In its first euthanasia case, the Supreme Court changed the prevailing interpretation of the Code of Criminal Law to another point. Furthermore, as shown, the new statutory interpretation deviates strongly from the position held by the Christian Democrats. So the interpretation the Supreme Court selected turns out to correspond with the prediction based on the policy advocate hypothesis.

\section{CONCLUSION}

Based on this analysis, the conserver hypothesis, which assumes that courts do not have substantive policy preferences and take the current statutory provisions as the starting point for their statutory interpretation, has not been supported by the outcome found for the euthanasia debate in the Netherlands. The Supreme Court did change the statutory interpretation, and this interpretation was not proximate to the policy position of the Christian Democrats, which coincides with the politically viable interpretation closest to the status quo. The outcome of the debate corresponds with the policy advocate hypothesis. This hypothesis predicts the observed change in statutory interpretation, and the outcome that was selected by the judiciary. The analysis supports the position of Spiller and others, who argue that courts have substantive policy preferences, ${ }^{46}$ rather than the Ferejohn-Weingast position, which claims that courts are less interested in

(F'note continued)

a treatment that aims to reduce a patient's suffering. However, the conscious ending of a person's life, as euthanasia has been defined in this article, remains a criminal offence.

${ }^{45}$ If the ideal point of the Supreme Court is found between the Christian Democrats and the Liberal party as indicated in Figure 2, the equilibrium interpretation will be equivalent to the Supreme Court's ideal point. If, however, the Supreme Court's most preferred point is found to the left of the policy position of the Liberal party, which is regarded as less likely, it will select the Liberal party position as the equilibrium interpretation.

46 See, for instance, Spiller and Gely, 'Congressional Control or Judicial Independence: The Determinants of US Supreme Court Labor-Relations Decisions, 1949-1988', and Spiller and Spitzer, 'Judicial Choice of Legal Doctrines'. 
policy outcomes than the original legislative understandings. They define this preference by assuming that the courts prefer to maintain the status quo.$^{47}$ In the case of euthanasia, however, the courts did not preserve these prior legislative values. Instead the Supreme Court selected a point that was closer to its own ideal point.

Following the model developed in this article, it is clear that differences in opinion between the political parties in a governing coalition allow the courts to select new statutory interpretations that cannot be changed by the legislature. Points that have this characteristic are found in the set of politically viable interpretations. In the case of euthanasia, by selecting an interpretation from this set, the Supreme Court made it impossible for the Christian Democrats to reach an agreement with the Liberals and the Labour party in successive cabinets. Furthermore, as coalition parties agreed to support cabinet initiatives only, they prevented the approval of other proposals, such as an opposition initiative.

A closer historical analysis of the decision-making process on euthanasia points to timing as an important factor, which is neglected in the model. The preferences of political parties may change rapidly, while it may take some time before a case is brought to court. To change statutory interpretations, the judiciary depends on cases coming before it. As a result, the moment a new interpretation is feasible, a case should exist in which the courts may express their views. While the non-religious parties held a more liberal opinion of euthanasia at the end of the 1970s, it took about four years before the first euthanasia case was brought before the Supreme Court. Meanwhile, the legislature was able to change the current legislation providing that the status quo was not a point in the set of politically viable interpretations. In the preceding section, this point was positioned equal to or to the right of the position of the Christian Democrats, which allows for two possible explanations. If the status quo was equivalent to the position of the Christian Democrats, legislation was not feasible, since the Christian Democrats would have blocked any deviation from their most preferred position. If the status quo was found to the right of this position, then the successive coalitions did not use their opportunity to introduce legislation, and they finally lost momentum in 1984.

The extent to which the policy positions of the political parties change, and the frequency with which new cases are brought to the courts, constitute two additional conditions for the model's successful application. If political parties have relatively stable preferences, and the judiciary is regularly confronted with new cases on a specific topic, which it can use to present new statutory interpretations, jurisprudence may develop permanently without legislative intervention. The model, as developed in this article, primarily applies to this setting. If, however, party preferences change rapidly, or if the frequency of cases that are considered is relatively low, courts will not always be able to give a new interpretation before new legislation has been initiated. Some elaboration of jurisprudence will be alternated with new legislation. In that case, the model,

${ }^{47}$ Ferejohn and Weingast, 'A Positive Theory of Statutory Interpretation'. 
which predicts no statutory change as a result of perfect anticipation on the part of the courts, will be less useful.

The distinction between court preferences and politically viable interpretations allows us to explain some of the dynamics of jurisprudence within the framework of the model. First, the judicial-legislative interaction, as described by the model, can lead to inertia, since the courts do not always respond to preference changes in the legislature. Inertia may arise when the ideal point of the courts is located in the set of politically viable interpretations. As long as preference changes in the legislature do not change this set beyond the courts' ideal point, the courts are not induced to alter their interpretation. Secondly, the interaction may lead to biased statutory interpretations, which deviate from the preferences of most representatives in parliament. If the courts have extreme preferences, that is, an ideal point that is not in the set of politically viable interpretations, they will select an interpretation from this set that is as close as possible to their ideal point. A statutory interpretation will then be equivalent to the ideal point of one of the extreme coalition members. Such a biased development of jurisprudence, without the possibility of direct legislative action, may encourage most parties in the legislature to seek additional controls on the judiciary in a future governing coalition. Finally, jurisprudence can be subject to sudden and discontinuous change. The courts can be induced to change their interpretation when, after a change in government or an autonomous change of party preferences, the set of viable interpretations is reduced so that they can no longer select their ideal point. After a period of inertia, the courts may suddenly introduce a new statutory interpretation. This response is not a result of new views within the judiciary, but critical preference changes within the governing coalition. Similarly, jurisprudence may become rigid after a period in which preference changes within the coalition have enlarged the set of viable interpretations so that it includes the ideal point of the courts.

The analysis in this article shows that the courts may play an important role in the policy-making process. By interpreting statutes, the courts are able to shift a statutory policy to a point that cannot be changed by the legislature. In the euthanasia case in the Netherlands, the Supreme Court selected a politically viable interpretation, which was invulnerable to legislative change. The Dutch courts and not the legislature decided on the admissibility of euthanasia. 